\title{
Assessment of the influence of mixed spiced diet on lipid profile of albino rats
}

\author{
*Nwachukwu. N. and Iweala E.E J \\ ${ }^{*}$ Department of Biochemistry, School of Sciences, Federal University of Technology, \\ P. M. B, 1526, Owerri Imo State Nigeria. \\ College of Science and Technology Biochemistry and Molecular Biology Unit, Covenant \\ University P. M. B, 1023, Ota Ogun State Nigeria.
}

\begin{abstract}
Two indigenous Nigerian spices-Gongronema latifolium (Utazi), and Ocimiuim gratissium (Ncheanwu) were used to formulate rat feed and assess their influence on the lipid profile. A total of forty-eight rats, mean body weight $118.12 \pm 13.31$ were divided into four different diet groups, last group (D) serving as control (No spice). Feeding was done twice daily for period of five months, while water was provided to all the animal ad. Libitum. Every two weeks, two rats were selected from each diet group and sacrificed for analysis. The following lipids, cholesterol (CHO), triacylglycerol (TG), High Density Lipoprotein (HDL), and low density lipoprotein (LDL) were assessed. The result shows that serum $\mathrm{CHO}$, TG, and LDL, generally significantly $(p \geq 0.05)$ decreased in all the diet groups, while the value of serum HDL increased. The highest reduction in the values of $\mathrm{CHO}$, and TG was observed in the diet groups with the mixed spices, and that with $G$. Iatifolium alone, while the highest reduction in the value of HDL occurred in diet group with O.gratissium, and the mixed spiced group respectively. The hypolipidemic effect of these spices individually and in combination form is important in nutritional management of cardio vascular diseases particularly atherosclerosis.
\end{abstract}

Keywords: Lipid profile, Indigenous spices, Nutritional therapy, Albino Rats.

\section{INTRODUCTION}

Spices whether exotic or indigenous are generally used to enhance taste, and improve appetite. The selected spices-Gongronema latifolium (utazi) and Ocimium gratissium (Ncheanwu) are probably among the most popular indigenous spices used in the Eastern part of Nigeria. Gongronema latifolium is rainforest plant of the family Asclapiadeceae, native of the south Eastern Nigeria, and some Asian countries. It has been widely used as a spice and as a medicinal herb (Morebise et al 2002), possesses antioxidant activity which could alleviant the oxidative stress associated with diabetes condition. Okafor et al (1993) also showed $G$. latifolium to be good in maintaining healthy blood glucose level. Similarly, high level of triacylglycerol and total cholesterol which are typical of the diabetic conditions, were significantly decreased by ethanolic extract of $G$. latifolium (Ugochukwu et al 2008).

Ocimium gratissium is a shrub often up to $1 \mathrm{~m}$ density and highly branched (WHO, 1990). It belongs to the family liabateae and is widely distributed in Nigeria, and used both as a spice and for medicinal purposes(Hartnett, 2002). $O$. gratissium is extensively used throughout West Africa as an anti malarial, anticonvulsant and in the treatment of cough (Okafor, 1996).

Combined spicing has become very popular in dishes because of the belief that taste, and hence appetite can be enhanced by increase in the number of spices in a single diet. However, literatures on positive influence of such combination on the supposed medicinal properties of the individual spices are few or completely lacking. In this study we assessed the influence of combining these spices on the lipid profile using albino rats as animal model.

\section{MATERIALS AND METHODS}

Sample Collection: The spices, Gongronema latifolium (utazi) and Ocimium gratissium (uziza) were bought from Central Market Nsukka, Enugu state of Nigeria, and were duly certified by a taxonomist from the Department of Botany University of Nigeria Nsukka. The samples were sorted to select good and uninfected one for oven drying, at $70^{\circ} \mathrm{C}$ to constant weight before grinding to powdered form with Authur Thomas milling machines. This was sieved with $1 \mathrm{~mm}$ sieve, and used to formulate the feed as shown below: 
Composition of diet groups

\begin{tabular}{|l|l|l|l|l|}
\hline Group & $\begin{array}{l}\text { Normal } \\
\text { Rat }\end{array}$ & $\begin{array}{l}\text { O. } \\
\text { gratissium } \\
(\mathrm{g})\end{array}$ & $\begin{array}{l}\text { G. } \\
\text { latifolium } \\
(\mathrm{g})\end{array}$ & $\begin{array}{l}\text { Total } \\
\text { composition } \\
(\mathrm{g})\end{array}$ \\
\hline I & 100.00 & - & - & 100.00 \\
\hline li & 70.00 & 30.00 & - & 100.00 \\
\hline lii & 70.50 & - & 30.00 & 100.00 \\
\hline Iv & 70.00 & 15.00 & 15.00 & 100.00 \\
\hline
\end{tabular}

Animal models and treatment: A total of forty eight adult male rats, mean body weight $118 . \pm 13.31 \mathrm{~g}$ were bought from the veterinary medicine faculty of university of Nigeria, Nsukka. They were divided into four equal groups of twelve rats according to the diet groups above and housed in a plastic cage. Water and normal rat feed were provided for one weak for acclimatization before introducing the compounded feed. Group (i) served as control while the other groups received the sample spices as shown above. Feeding was done twice daily for three months while analysis was done bi-weekly.

Preparation of serum: Eighteen hours after the last feeding, two rats were selected from each diet group and sacrificed under light chloroform anesthesia. Sterilized dissecting scissors were used to open the thoracic cavity while $5.0 \mathrm{ml}$ of blood was collected by cardiac puncture into a test tube using syringe. After $30 \mathrm{~min}$, the blood was centrifuged (Gallenkamp, 04062) at $8,000 \mathrm{rpm}$ for $10 \mathrm{~mm}$; and the supernatant collected and used for analysis.

Determination of lipids: Serum cholesterol was determined by the method of Alexander et al, (1993) while triacylglycerol, high density lipoprotein (HDL), and low density lipoproteins (LDL) were determined according to the method of Curtins and Marc, (1974).

\section{RESULTS/ DISCUSSION}

In table 1 the results showed that serum values of cholesterol, triacylglycerol and low density lipoprotein decreased significantly $(p \leq 0.05)$ following the administration of the individual spice (Group ii and iii) and when combined in equal proportion (group iv). The mixed spices exerted the greatest reduction in $\mathrm{CHO}$ and LDL respectively while the greatest reduction in TG was achieved by $G$. latifolium alone. The results of the chronic administration of the spices(Fig. i-iv) on serum values of these lipids ( $\mathrm{CHO}, \mathrm{TG}$ and $\mathrm{HDL}$ ) followed the same pattern. It is also important to point that these decreases were time dependent (the longer the time of administration the greater the reduction effect). Nwachukwu and lbe (2009) working with equal amount of Cymbopogon citratus and Gongronema latifolium observed the same pattern of hypolipidemic effect and concluded that such combination could be effective in combating coronary heart diseases. Okafor(1993) also showed that $G$. latifolium alone decreased cholesterol and triacylglycerol level in rats. Gingiber officinale (Ginger) another spices was shown also to posses hypocholesterolemic effect due to gingerol content. According to Shoji and Iwasa(1982), gingerol produced concentration dependent positive entropic effect on isolated Guinea pig ataria due to stimulation of $\mathrm{Ca}^{2}+$ uptake by sarcoplasmic reticulum. Garlic is also another spices that the lowering effect on lipids and cholesterol levels in rats and LDL cholesterol in human has been reported (Sanjay and Subir, 2002).

Possible mechanism of hypocholesterolemic effect could be by conversion to bile acid since decrease in HDL may affect the reverse transport of cholesterol to the liver for biosynthesis (Srinivasan and Sambaiah, 1991). The role of lipids particularly cholesterol in the aetiology of coronary heart diseases $(\mathrm{CHO})$ is well documented in literature (Davies, 2000; Laharthe, 1998). In fact, part of treatment and management of $\mathrm{CHO}$ is to reduce cholesterol and replace saturated with unsaturated or polyunsaturated fats in the diet. Even drugs like vastatin series act by inhibiting cholesterol synthesis and thus increasing the degradation (Downs, 1998).

Both LDL, and HDL play important roles in cholesterol metabolism. For example, LDL content in the arterial intima accounts for cholesterol build up due to certain reasons like the small size, fragile nature, and easy of oxidation. This implies that LDL easily breaks down depositing cholesterol within the arterial wall which later develops into atherosclerotic plague (Davies 2000). However, HDL has higher molecular weight, more stable with antioxidant properties, and transport cholesterol from the arterial intima back to the liver (Reverse transport) where it is used for biosynthesis. Therefore, higher levels of HDL favours cholesterol clearance (Srinivasan and Sambaiah, 1991).

In summary, the hypo lipidemic effect of these spices individually and in mixed proportion has been highlighted with the mixed spices in equal proportion exerting greatest reduction effect. The same result was sustained throughout the period of the study. The study also shows that the hyppolipidemic effect is time dependent - the longer the period of study the 
greater the reduction effect. Therefore, when these spices are used for medicinal purposes in the treatment and management of coronary heart disease, they should be mixed in equal proportion and for a prolonged period in order to get the best result.

Table 1: Effect of MSD on lipid profile of albino Rats.

Lipid (mg/ml)

\begin{tabular}{|l|c|c|c|c|}
\hline Group & CHO & TG & HDL & LDL \\
\hline I & $111.50 \pm 3.10$ & $204.66 \pm 8.47$ & $54.00 \pm 0.07$ & $70.86 \pm 2.30$ \\
\hline Ii & $113.10 \pm 0.70$ & $195.33^{\star} \pm 0.93$ & $55.40 \pm 1.10$ & $65.20^{\star} \pm 2.30$ \\
\hline lii & $108.10^{\star} \pm 0.10$ & $130.00^{\star} \pm 2.80$ & $55.40 \pm 0.30$ & $66.90^{\star} \pm 0.70$ \\
\hline Iv & $107.00^{\star} \pm 1.50$ & $194.00^{\star} \pm 0.93$ & $56.30 \pm 2.30$ & $62.70^{\star} \pm 2.70$ \\
\hline
\end{tabular}

All values are \pm SEM $n=3$

* Significant $P \leq 0.05$

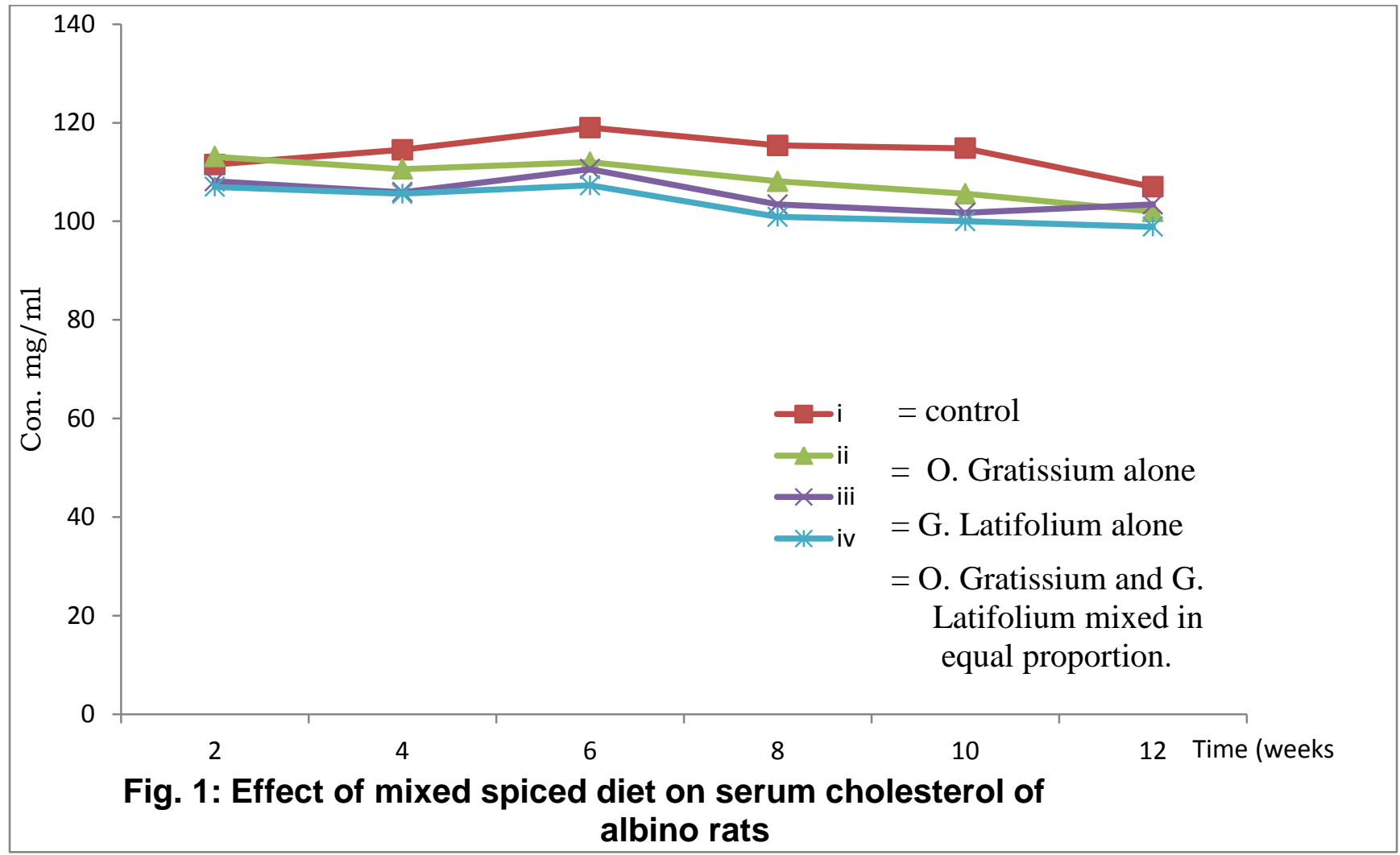



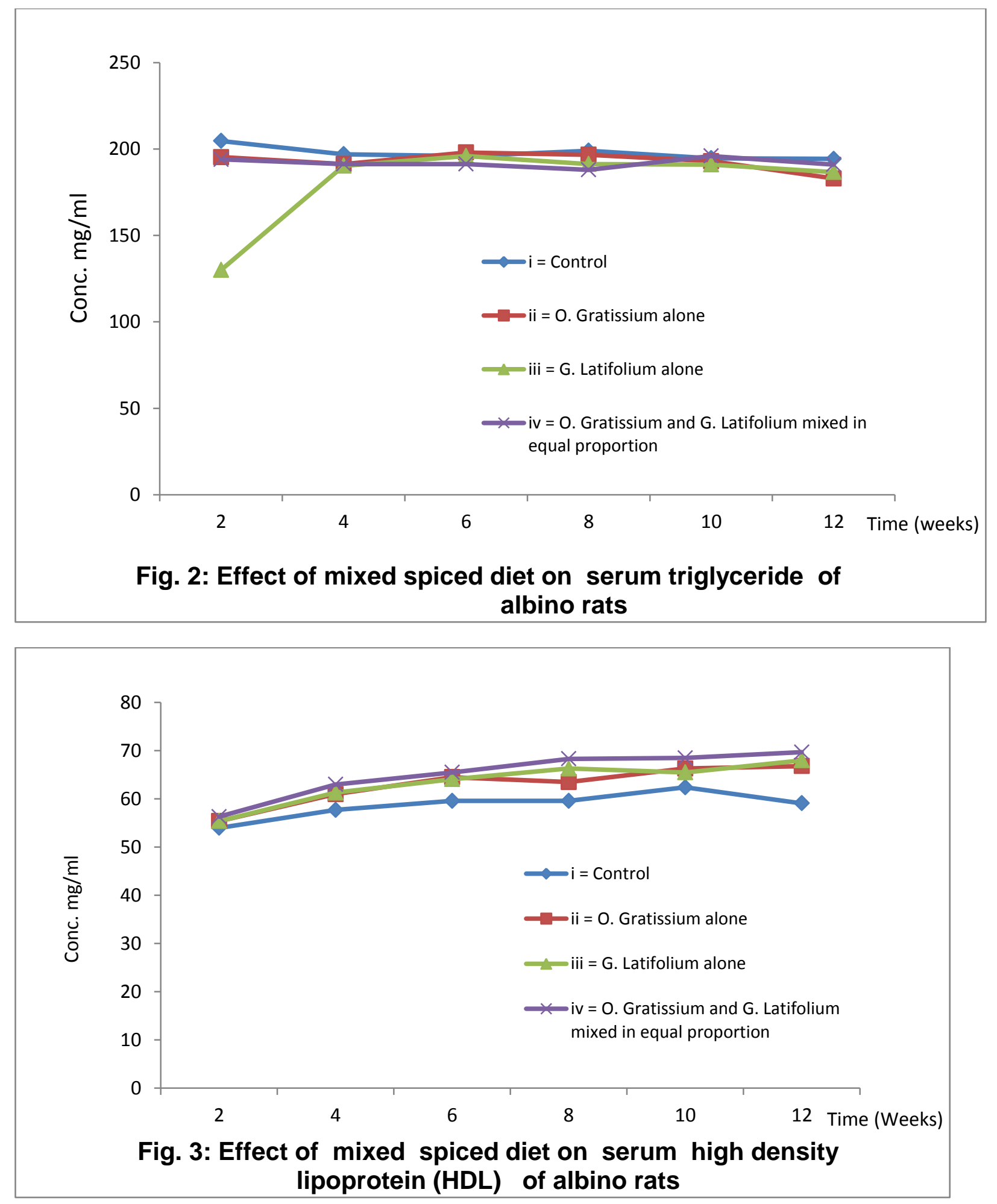
Am. J. Food. Nutr, 2013, 3(3): 117-121

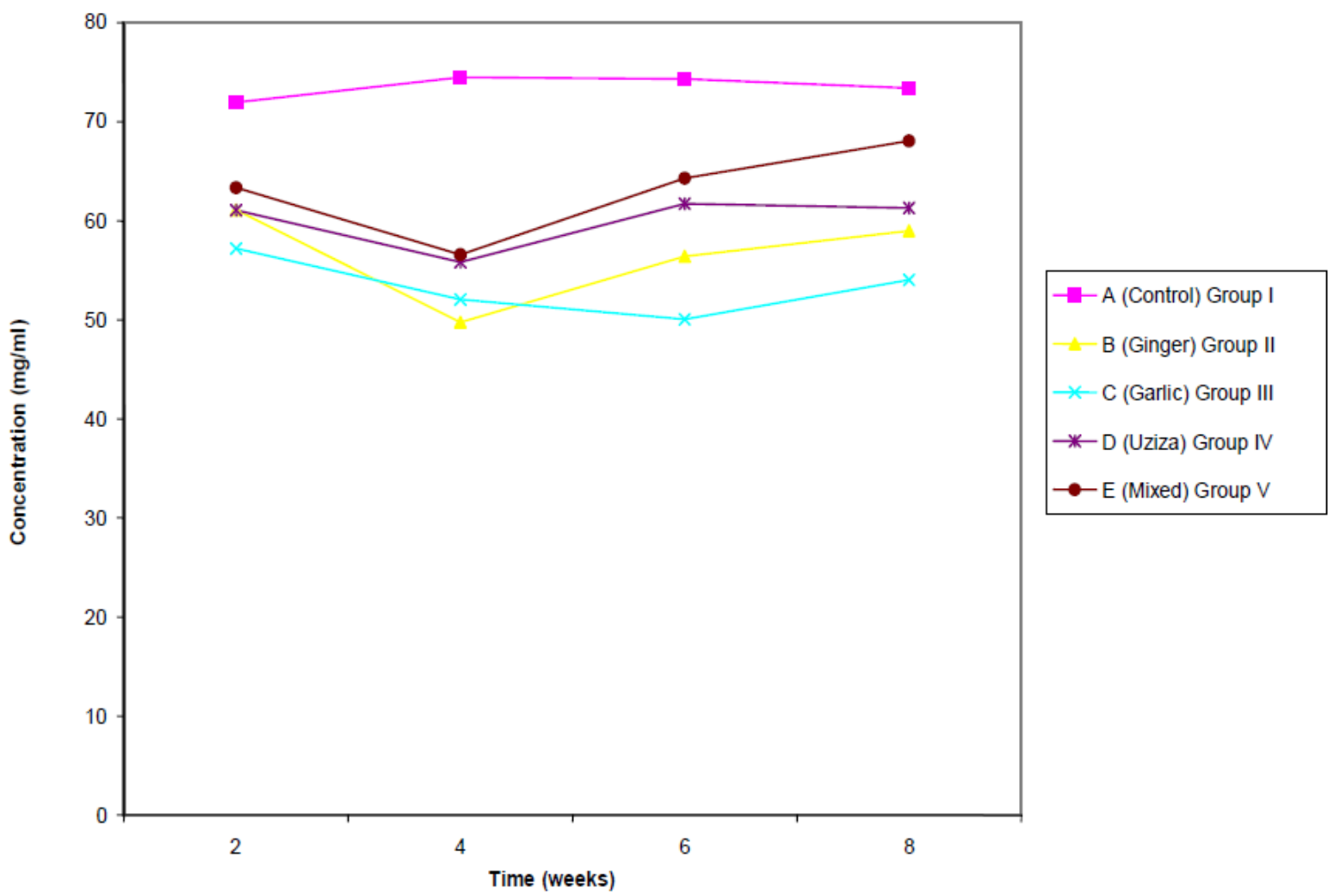

Fig.4: Effect of mixed spiced diet on serum low density lipoprotein (LDL) of Albino Rats.

\section{REFERENCES}

Alexander, R.R \& Ariffiths, J.M. (1993). Basic Biochemical Method. Wiley Inc. New York, USA.

Curtins, H.C. \& Roth, M. (1994). Clinical Biochemistry Principles and methods. Walter de Gruyte-Birlin. New York, USA.

Davies, M.J. (2000). The Pathophybiology of Acute Coronary Heart Disease. Paul Duddey, White Lectures. 94, 2013-202.

Downs, J.R. (1993). Primary Preventions of Acute Coronary Events with Lovastation in men and Women with Average Cholesterol Level. J. Am. Med. 20; 1615-1622.

Hartneth, E. M. Stratton, R.D. Browne, R.W; rosner B.A; Larham, R.J. and Armstrong, D. (2010). Serum Marketers of Oxidative Stress and Severity of diabetic retinopathy. Diabete care. 23; 234-240.

Laharthe, D.R. (1998) . Cardiovascular Disease a Global Public health Challenge. Aspen Publi. U.S.A

Morebise, O. Fafunsho, M. A. Makinde, J. M. Olajide, O. A. and Awe,E.O.(2002).Antiinflammatory property of the leaves of Gongronema latifolium. Phytochem. Res.16: 75-77.
Nwachukwu, N and Ibeh, G. (2009). Influence of diet formulated with two Indigenous Spices on Serum Lipid and Liver Enzymes of Albino Rats. Pakistan J. Nutrition, 8 (1).

Okafor, J. C. (1996). Useful tropical plants in health care delivery. Lecture delivered at the $6^{\text {th }}$ Annual conf. of the Nigerian society of Pharmacognosy, UNN.

Okafor, J. C. (1993). Horticultural promising indigenous wild plant species of the Nigerian forest zone. Acta. Hort. $123,165-175$.

Sanjay, K. B. and Subir, K. M. (2002). Effect of Garlic on cardiovascular disorder. Nutrition Jour. 1, 1186-1192.

Shoji, N, and Iwasa, A. (1982). Calcitonic principle of Gingerol. Japan Jour. Of Pharmacy.6, 1174-1181.

Srinivasan, K. and Sambaiah, K. (1991).The effect of spices on cholesterol 7 , hydroxylase activity on serum and hepatic cholesterol levels in the Rat.Int. Jour. Vit. Nutr. Res.61, 364-

Ugochukwu, N. H. Bachy, N. E. Garland, C. M. and Gasset, S. (2003). The effect of Gongronema latifolium spice on lipid profile of Rats. Jour. Biosci. 28, 1-5.

WHO. (1990). Medicinal plants in Vietnam. Regional publications; Western Pacific series, Vol. 3. 